\title{
FORMATION ENERGETICS OF CERAMIC PHASES RELATED TO SURPLUS PLUTONIUM DISPOSITION
}

\author{
Robert L. Putnam * and Ubaldo F. Gallegos Los Alamos National Laboratory; NMT-16 Mail \\ Stop G730; Los Alamos, NM 87545.
}

Bart B. Ebbinghaus Lawrence Livermore National Laboratory; P.O.Box 808; Livermore, CA 94551

Alexandra Navrotsky, Katheryn B. Helean, and Sergey V. Ushakov Thermochemistry Facility; The University of California, Davis; Department of Chemical Engineering and Materials Science; Davis, CA 95616.

Brian F. Woodfield and Juliana Boerio-Goates Department of Chemistry and Biochemistry; Brigham Young University; C100 BNSN; Provo, UT 84602

Mark A. Williamson Argonne National Laboratory; Chemical Technology Division - Bldg. 205; 9700 South Cass Ave.; Argonne, IL 60439

\begin{abstract}
A database of fundamental thermodynamic functions at $298.15 \mathrm{~K}$ including entropy, $S^{o}$, standard enthalpies and Gibbs free energies of formation, $\Delta_{f} H^{\circ}$ and $\Delta_{f} G^{\circ}$, molar masses, and molar volumes, $V^{o}$, for phases related to proposed ceramic waste materials for the disposal of surplus weapons plutonium has been assembled. Previously published as well as newly reported results of measured and predicted quantities for pyrochlore, brannerite, monazite, zircon and other related phases are presented. Where thermodynamic quantities are available for temperatures above $298.15 \mathrm{~K}$, they are included or referenced.
\end{abstract}

\section{INTRODUCTION}

With a landmark record of decision ${ }^{(1)}$, the U.S. Department of Energy has decreed that at least $17 \cdot 10^{3} \mathrm{~kg}$ of surplus weapons plutonium will be incorporated into a ceramic waste material. Another $33 \cdot 10^{3} \mathrm{~kg}$ is expected to be used in mixed-oxide (MOX) fuel reactors and the resulting irradiated fuel is to be considered a waste material. Both waste ceramics will be buried in a geological repository such as the proposed Yucca Mountain nuclear waste repository in the state of Nevada in the United States of America. Licensing of each waste material for incorporation into a waste repository will require clear and predictive scientific results on their durability and performance in a geological environment over nearly $10^{6}$ years. Accurate thermodynamic quantities are key to both the development and modeling of these waste materials.

In an effort to facilitate the optimization of a ceramic waste form, enable accurate modeling of its performance in a geological repository, and to provide a thermodynamic basis for production process engineering, we have sought to provide accurate thermodynamic quantities for phases related to these waste materials. Here, we report molar masses, molar volumes, $V^{o}$, heat capacities, $C_{p}^{o}$, entropies, $S^{o}$, enthalpies, $\Delta_{f} H^{o}$, and Gibbs free energies, $\Delta_{f} G^{o}$, of formation for phases related to these proposed ceramic waste materials for surplus weapons plutonium. The

\footnotetext{
* Author to whom correspondence should be sent.
}

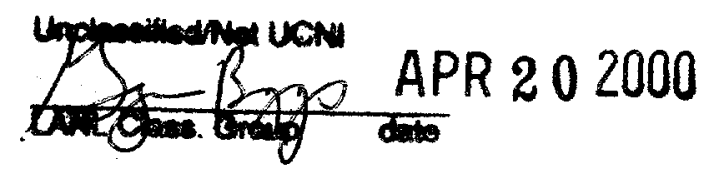




\section{DISCLAIMER}

This report was prepared as an account of work sponsored by an agency of the United States Government. Neither the United States Government nor any agency thereof, nor any of their employees, make any warranty, express or implied, or assumes any legal liability or responsibility for the accuracy, completeness, or usefulness of any information, apparatus, product, or process disclosed, or represents that its use would not infringe privately owned rights. Reference herein to any specific commercial product, process, or service by trade name, trademark, manufacturer, or otherwise does not necessarily constitute or imply its endorsement, recommendation, or favoring by the United States Government or any agency thereof. The views and opinions of authors expressed herein do not necessarily state or reflect those of the United States Government or any agency thereof. 


\section{DISCLAIMER}

Portions of this document may be illegible in electronic image products. Images are produced from the best available original document. 
non-MOX plutonium will use a solid solution between $\mathrm{Hf}$-zirconolite, $\mathrm{CaHfTi}_{2} \mathrm{O}_{7}$, and the end member pyrochlores $\mathrm{Gd}_{2} \mathrm{Ti}_{2} \mathrm{O}_{7}, \mathrm{CaUTi}_{2} \mathrm{O}_{7}$, and $\mathrm{CaPuTi}_{2} \mathrm{O}_{7}$ as a waste ceramic, while the MOX fuel will be disposed of directly after irradiation.

To date, the energetics of mixing between the end member phases noted above and those that would be used for a MOX fuel are not known. We therefore do not include thermodynamic quantities for mixed phases and solid solutions at this time. We hope to include them in a future revision of this database once they are determined. Such calorimetry work is in progress.

The reader will note that quantities for binary oxides (e.g., $\mathrm{MO}_{\mathrm{x}}$ ) and elements in their standard states are also reported or referenced along with the thermodynamic quantities for higher order oxide materials. We include these quantities to create an internally consistent database of thermodynamic quantities. Included in this database are all of the fundamental thermodynamic data that have been used in determining the measured or predicted quantities reported here.

\section{NOTATION AND TERMINOLOGY}

The symbols and terminology used here for thermochemical quantities and units are consistent with those used in the widely accepted NIST-JANAF thermochemical tables. ${ }^{(2)}$ The standard state pressure is $1 \mathrm{~atm}(101325 \mathrm{~Pa})$. The standard state temperature is $298.15 \mathrm{~K}$. Where a quantity is valid at a temperature other than $298.15 \mathrm{~K}$, a superscript $\mathrm{T}$ is used to the left of the thermodynamic symbol. (e.g., $\Delta_{f} H^{\circ}=$ the standard enthalpy of formation at $298.15 \mathrm{~K}$ and $\Delta_{f}^{T} H^{o}=$ the standard enthalpy of formation at $\mathrm{T} \neq 298.15 \mathrm{~K}$.) The value of $\mathrm{T}$ will be defined in the table where the quantity is listed. Symbols used to designate phases or states of aggregation are as follows: $\mathrm{g}$ - gas, cr - crystalline solid, and [allotrope] to designate a specific crystal structure for materials with multiple allotropes (e.g., $\mathrm{TiO}_{2}$ [cr, anatase] versus $\mathrm{TiO}_{2}$ [cr, rutile]) Units are standard SI units and are noted in the table column headings. Our reference atomic masses for the elements are taken from reference 3 except for that of $\mathrm{Pu}$. For the atomic mass of $\mathrm{Pu}$ we adopt the isotopic mass of ${ }^{239} \mathrm{Pu} .{ }^{(4)}{ }^{239} \mathrm{Pu}$ is the principal isotope found in the surplus weapons material. Molecular masses for compounds listed in Table 1 are calculated in this work from the reference atomic weights as noted above.

\section{THERMODYNAMIC DATA}

Table 1 contains a summary of fundamental thermodynamic quantities valid at $298.15 \mathrm{~K}$ for several pyrochlore, brannerite, monazite, and zircon compositions as well as other, related, phases. Where noted, some values have been estimated from periodic systematics as described by Putnam ${ }^{5}$ previously. Also reported in Table 1, where applicable, are the formation enthalpies of these phases from the binary oxides (equation 1) or from the binary oxides and perovskite, $\mathrm{CaTiO}_{3}$ (equation 2). Examples of these reactions are given below for the formation of zirconolite ${ }^{6}$, $\mathrm{CaZrTi}_{2} \mathrm{O}_{7}$.

$$
\begin{aligned}
& \mathrm{CaO}(\mathrm{cr})+\mathrm{ZrO}_{2} \text { (cr, baddeleyite) }+2 \mathrm{TiO}_{2} \text { (cr, rutile) }=\mathrm{CaZrTi}_{2} \mathrm{O}_{7}(\mathrm{cr} \text {, zirconolite }) \\
& \mathrm{CaTiO}_{3}(\mathrm{cr} \text {, perovskite })+\mathrm{ZrO}_{2}(\mathrm{cr} \text {, baddeleyite })+\mathrm{TiO}_{2} \text { (cr, rutile) }=\mathrm{CaZrTi}_{2} \mathrm{O}_{7}(\mathrm{cr} \text {, zirconolite })
\end{aligned}
$$

A thermodynamically stable phase should have a negative free energy change for reactions of both type (1) and type (2).

Table 2 contains summaries of the fundamental thermodynamic quantities as a function of temperature for some of the higher order oxide materials found in Table 1 and references to similar data on the binary oxides and elements.

\section{ACKNOWLEDGEMENTS}

This work was supported in part by a grant from Lawrence Livermore National Laboratory (BYU) and by a Department of Energy grant number DE-FG07-97ER45673 (UCD, LANL, and LLNL). 


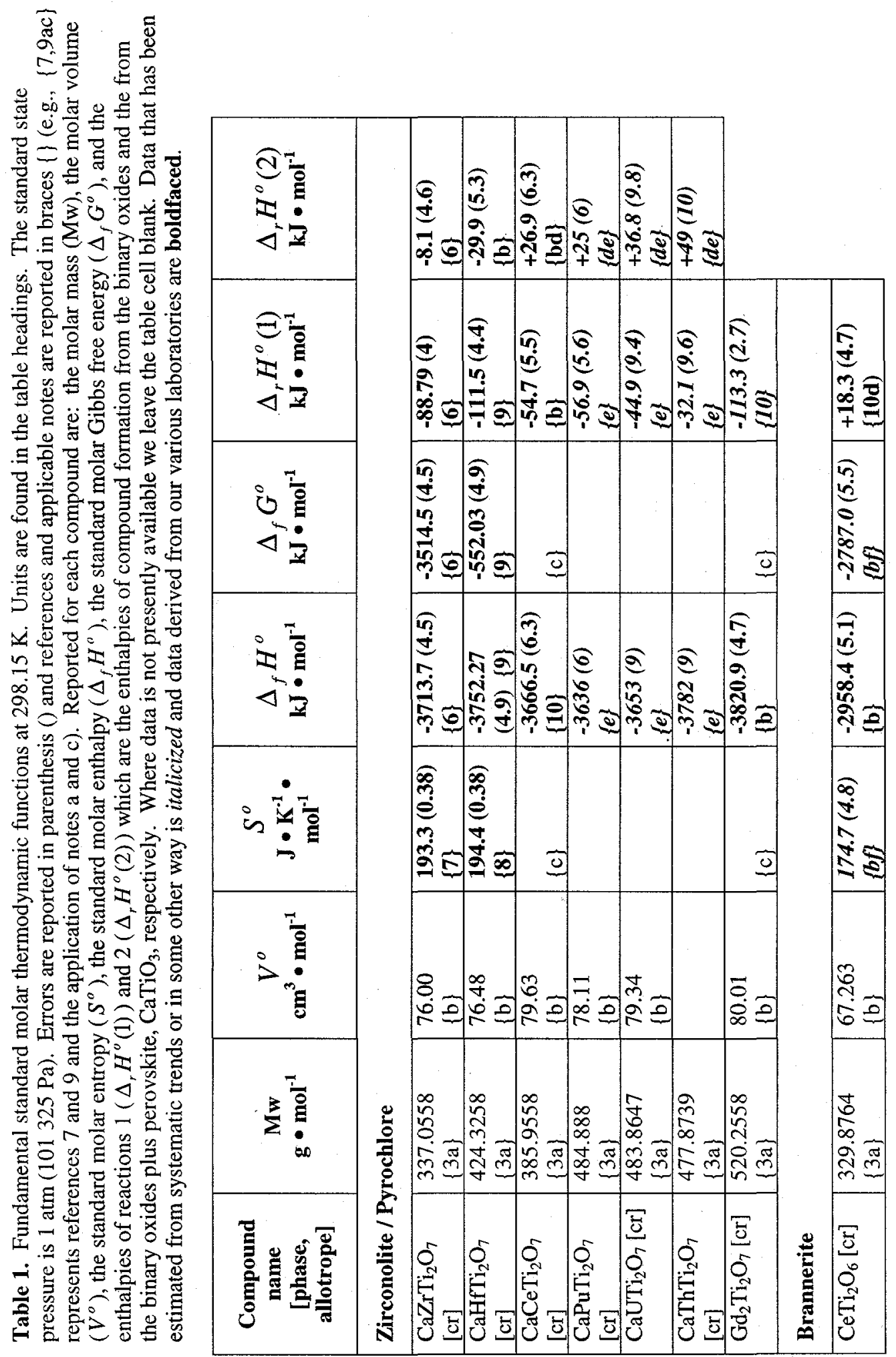




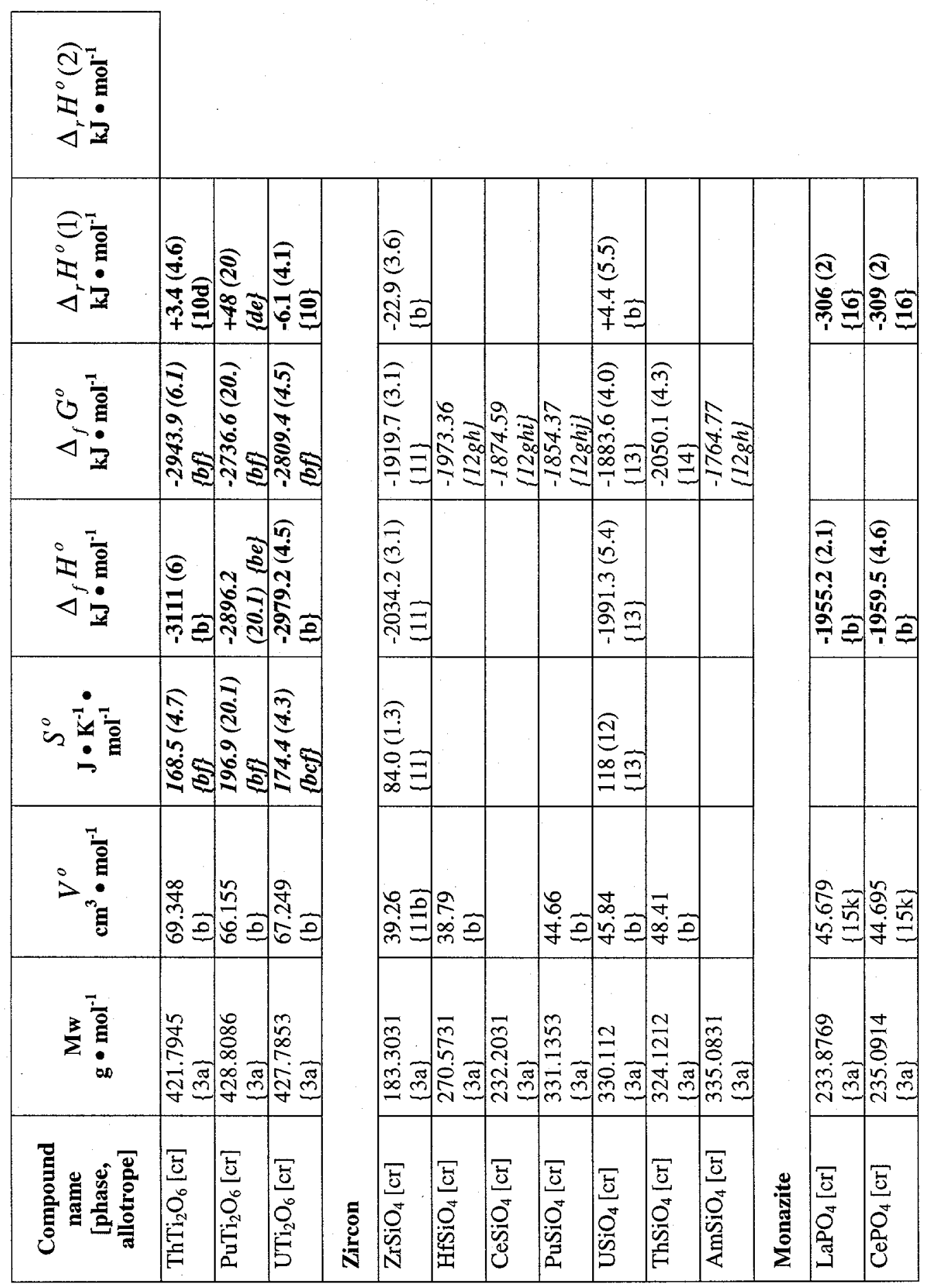




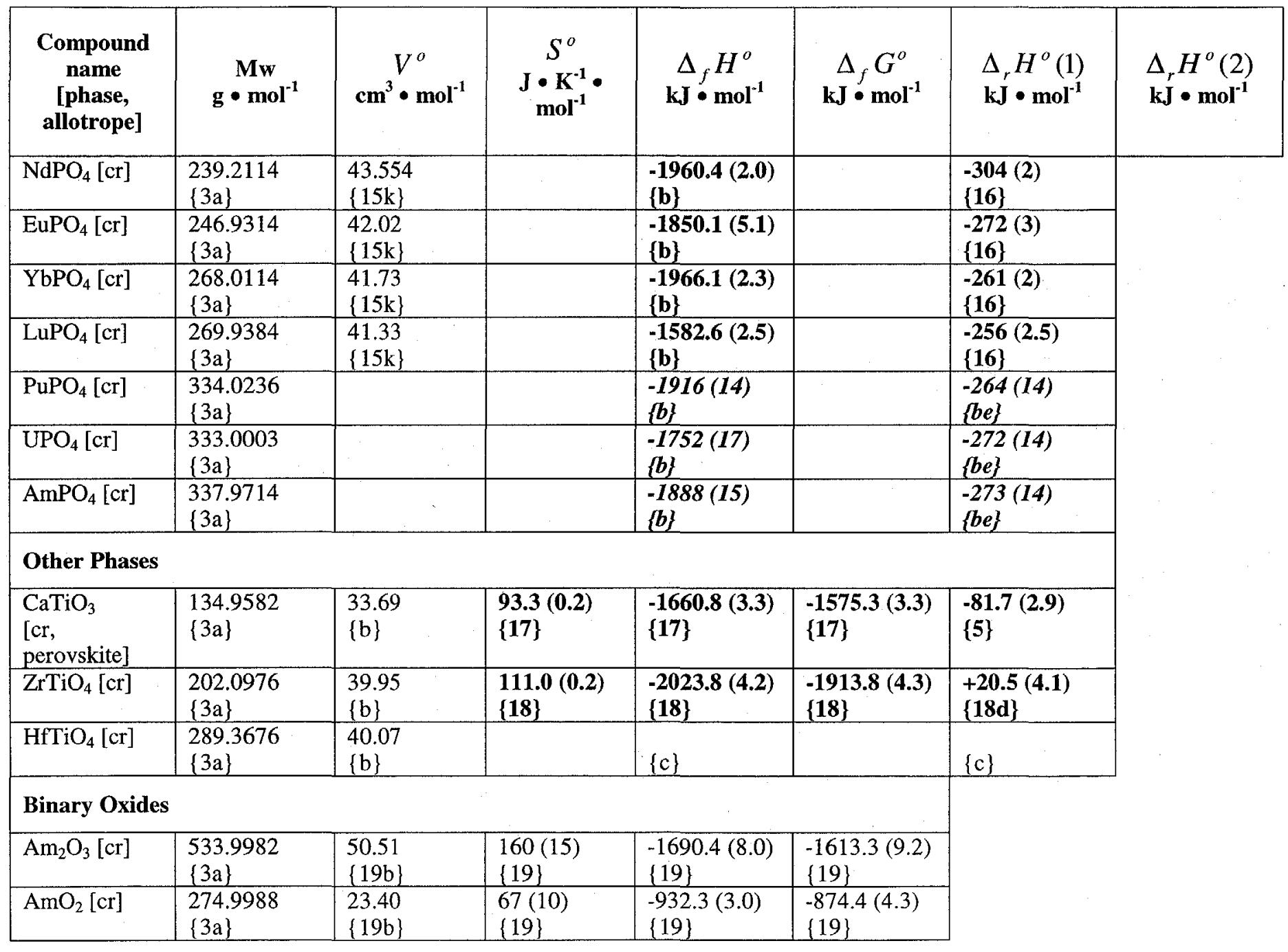




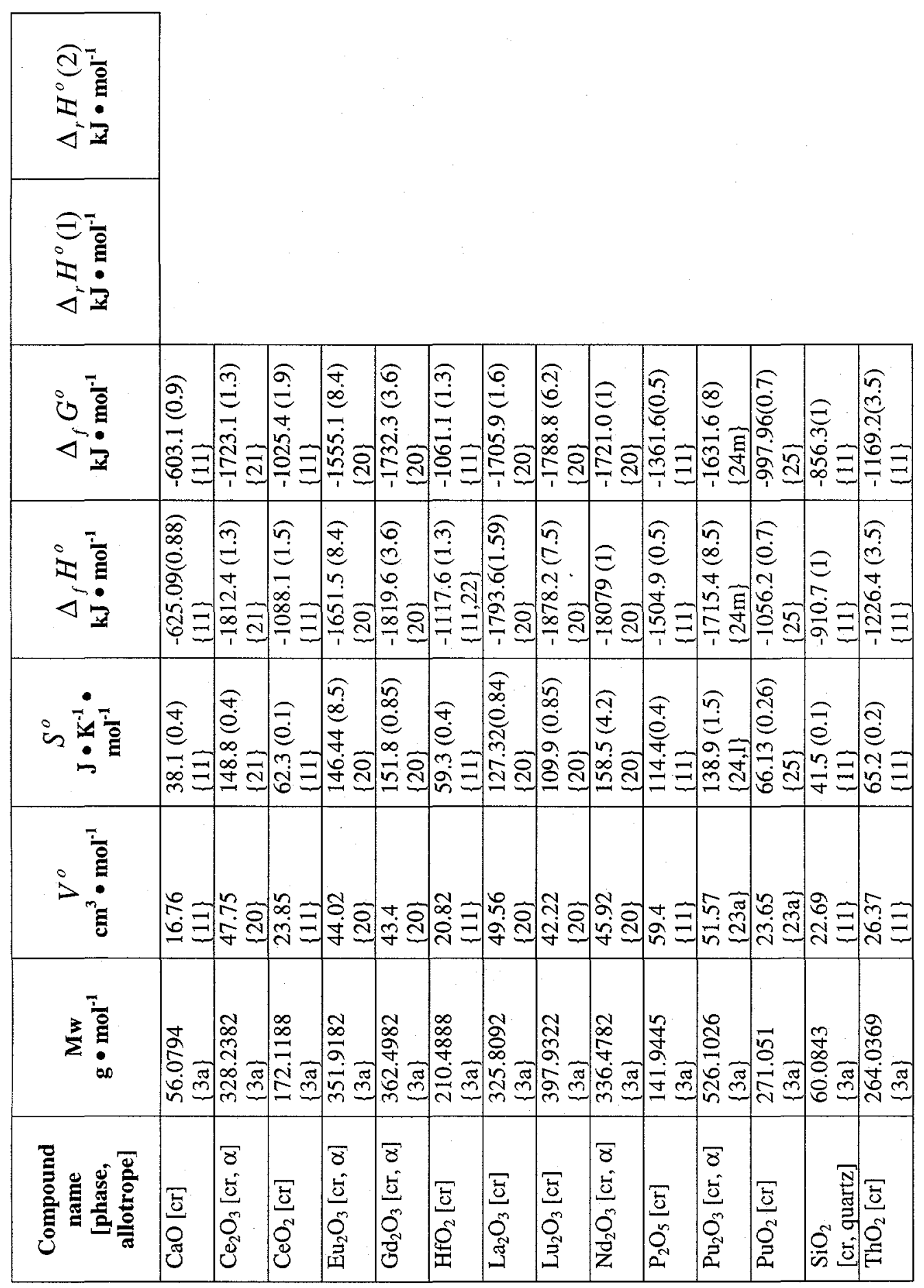




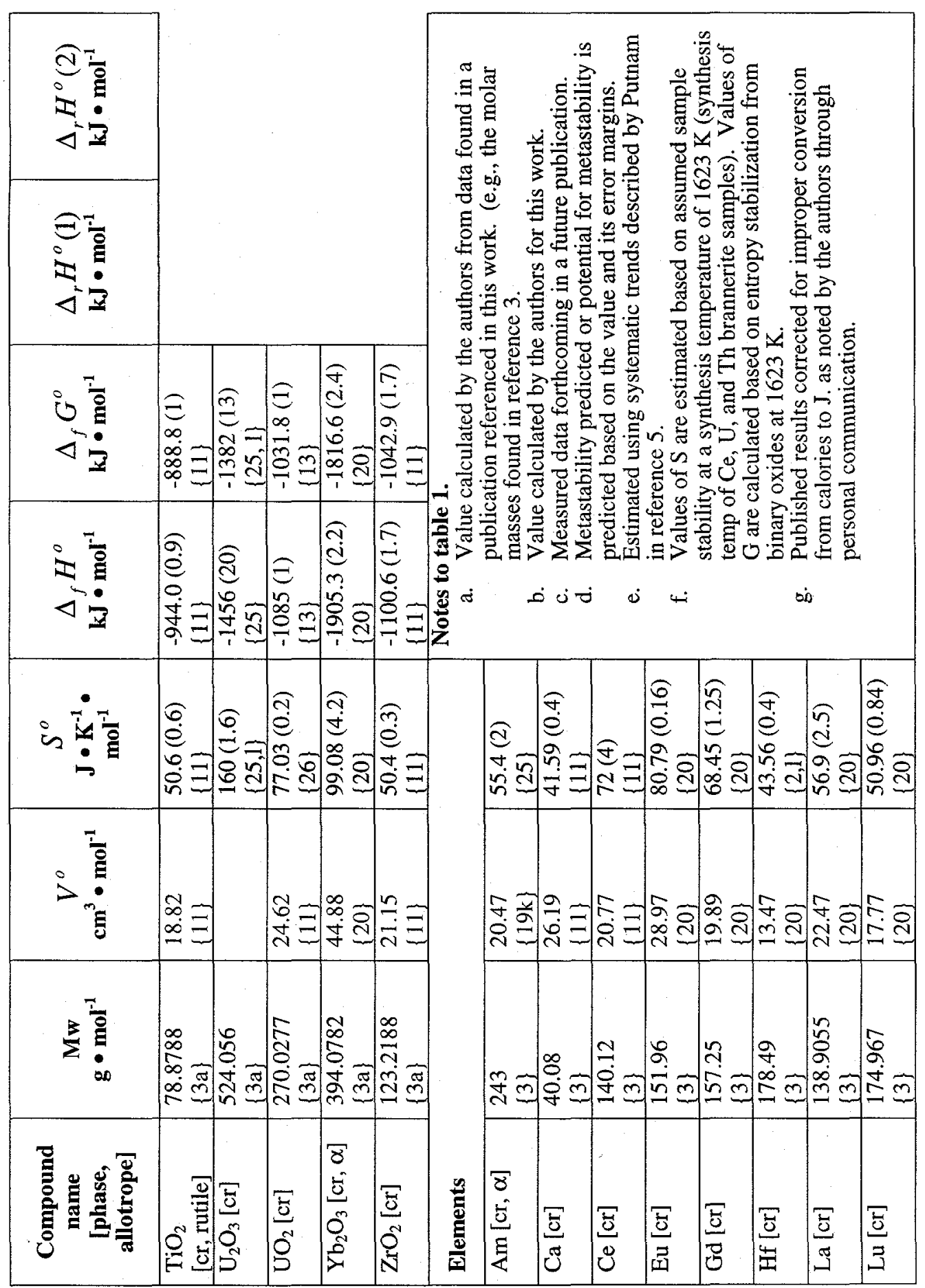




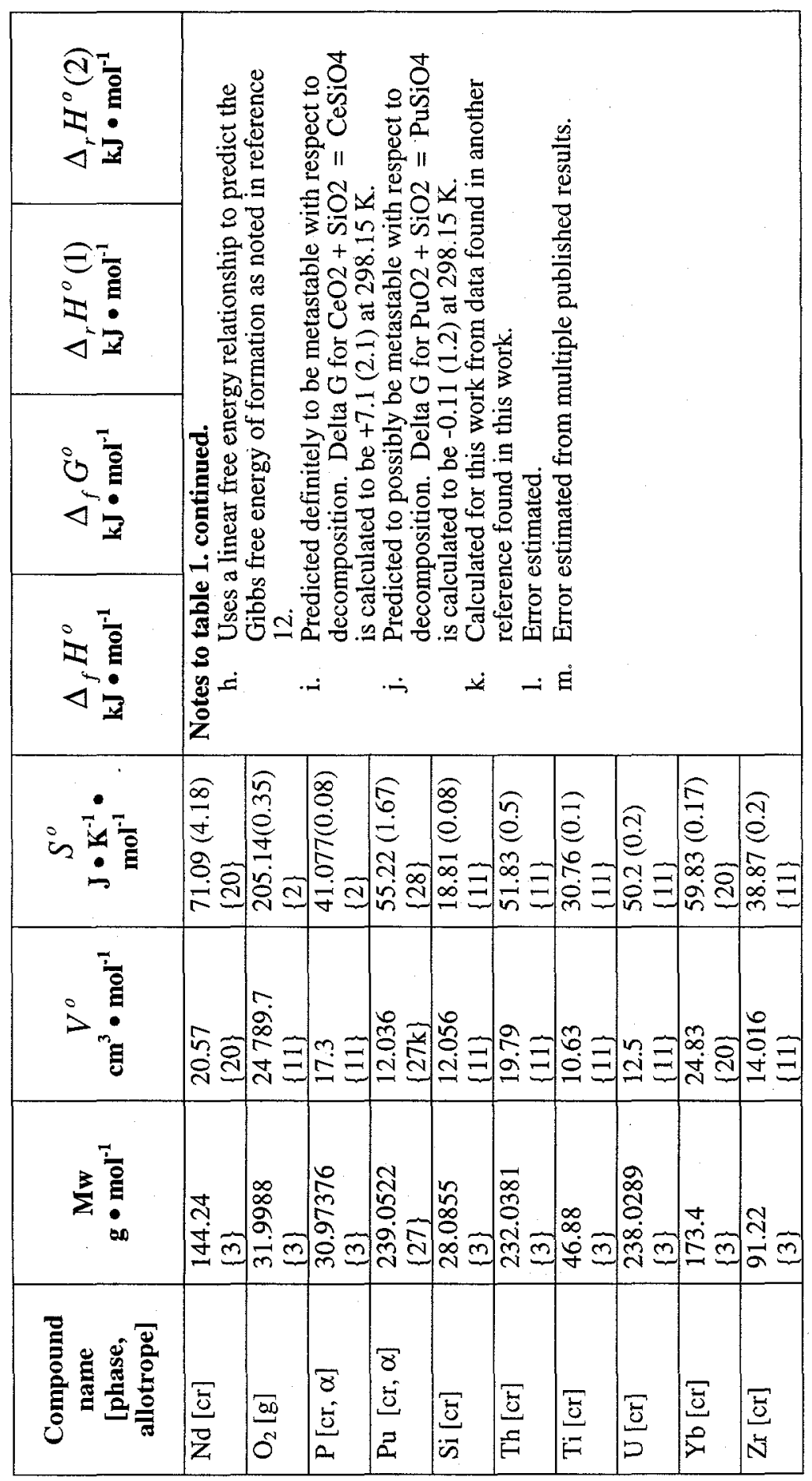


Table 2 Fundamental standard molar thermodynamic functions at temperatures other than 298.15 $\mathrm{K}$. Data that has been derived from our various laboratories are boldfaced.

\begin{tabular}{|c|c|c|c|}
\hline Compound & $\begin{array}{c}\text { Thermodynamic } \\
\text { Quantities Reported }\end{array}$ & $\begin{array}{c}\text { Valid Temperature } \\
\text { range. }\end{array}$ & Reference \\
\hline $\mathrm{CaZrTi}_{2} \mathrm{O}_{7}[\mathrm{cr}]$ & $\mathbf{C}_{\mathbf{p}},{ }^{T} S^{o}, \Delta_{f}^{T} H^{o}, \Delta_{f}^{T} G^{o}$ & 298.15 to $1500 \mathrm{~K}$ & 6 \\
\hline $\mathrm{CaHfTi}_{2} \mathrm{O}_{7}[\mathrm{cr}]$ & $\mathbf{C}_{\mathbf{p}},{ }^{T} S^{o}, \Delta_{f}^{T} H^{o}, \Delta_{f}^{T} G^{o}$ & 2989.15 to $1500 \mathrm{~K}$ & 9 \\
\hline $\mathrm{CaCeTi}_{2} \mathrm{O}_{7}[\mathrm{cr}]$ & $\mathbf{C}_{\mathbf{p}},{ }^{T} S^{o}, \Delta_{f}^{T} H^{o}, \Delta_{f}^{T} G^{o}$ & 0 to $1500 \mathrm{~K}$ & Note a \\
\hline $\mathrm{Gd}_{2} \mathrm{Ti}_{2} \mathrm{O}_{7}[\mathrm{cr}]$ & $\mathbf{C}_{\mathbf{p}},{ }^{T} S^{o}, \Delta_{f}^{T} H^{o}, \Delta_{f}^{T} G^{o}$ & 0 to $1500 \mathrm{~K}$ & Note a \\
\hline $\mathrm{CeTi}_{2} \mathrm{O}_{6}[\mathrm{cr}]$ & $\mathbf{C}_{\mathrm{p}},{ }^{T} S^{o}, \Delta_{f}^{T} H^{o}, \Delta_{f}^{T} G^{o}$ & 0 to $1500 \mathrm{~K}$ & Note a \\
\hline $\mathrm{ZrSiO}_{4}[\mathrm{cr}]$ & $\mathrm{C}_{\mathrm{p}}{ }^{T} S^{o}, \Delta_{f}^{T} H^{o}, \Delta_{f}^{T} G^{o}$ & 298.15 to $1600 \mathrm{~K}$ & 11 \\
\hline $\mathrm{CaTiO}_{3}[\mathrm{cr}$, perovskite] & $\mathbf{C}_{\mathrm{p}},{ }^{T} S^{o}, \Delta_{f}^{T} H^{o}, \Delta_{f}^{T} G^{o}$ & 0 to $1900 \mathrm{~K}$ & 17 \\
\hline $\mathrm{ZrTiO}_{4}[\mathrm{cr}]$ & $\mathbf{C}_{\mathbf{p}},{ }^{T} S^{o}, \Delta_{f}^{T} H^{o}, \Delta_{f}^{T} G^{o}$ & 0 to $1400 \mathrm{~K}$ & 18 \\
\hline $\mathrm{CaO}[\mathrm{cr}]$ & $\mathrm{C}_{\mathrm{p}},{ }^{T} S^{o}, \Delta_{f}^{T} H^{o}, \Delta_{f}^{T} G^{o}$ & 298.15 to $1800 \mathrm{~K}$ & 11 \\
\hline $\mathrm{Ce}_{2} \mathrm{O}_{3}[\mathrm{cr}, \alpha]$ & $\mathrm{C}_{\mathrm{p}},{ }^{T} S^{o}, \Delta_{f}^{T} H^{o}, \Delta_{f}^{T} G^{o}$ & 298.15 to $1500 \mathrm{~K}$ & 21 \\
\hline $\mathrm{CeO}_{2}[\mathrm{cr}]$ & $\mathrm{C}_{\mathrm{p}},{ }^{T} S^{o}, \Delta_{f}^{T} H^{o}, \Delta_{f}^{T} G^{o}$ & 298.15 to $1800 \mathrm{~K}$ & 11 \\
\hline $\mathrm{Eu}_{2} \mathrm{O}_{3}[\mathrm{cr}, \alpha]$ & $\mathrm{C}_{\mathrm{p}},{ }^{T} S^{o}, \Delta_{f}^{T} H^{o}, \Delta_{f}^{T} G^{o}$ & 298.15 to $1800 \mathrm{~K}$ & 20 \\
\hline $\mathrm{Gd}_{2} \mathrm{O}_{3}[\mathrm{cr}, \alpha]$ & $\mathrm{C}_{\mathrm{p}},{ }^{T} S^{o}, \Delta_{f}^{T} H^{o}, \Delta_{f}^{T} G^{o}$ & 298.15 to $1800 \mathrm{~K}$ & 20 \\
\hline $\mathrm{HfO}_{2}$ [cr] & $\mathbf{C}_{\mathbf{p}},{ }^{T} S^{o}, \Delta_{f}^{T} H^{o}, \Delta_{f}^{T} G^{o}$ & 298.15 to $1500 \mathrm{~K}$ & 9 \\
\hline $\mathrm{La}_{2} \mathrm{O}_{3}[\mathrm{cr}]$ & $\mathrm{C}_{\mathrm{p}},{ }^{T} S^{o}, \Delta_{f}^{T} H^{o}, \Delta_{f}^{T} G^{o}$ & 298.15 to $1800 \mathrm{~K}$ & 20 \\
\hline $\mathrm{Lu}_{2} \mathrm{O}_{3}[\mathrm{cr}]$ & $\mathrm{C}_{\mathrm{p}},{ }^{T} S^{o}, \Delta_{f}^{T} H^{o}, \Delta_{f}^{T} G^{o}$ & 298.15 to $1800 \mathrm{~K}$ & 20 \\
\hline $\mathrm{Nd}_{2} \mathrm{O}_{3}[\mathrm{cr}, \alpha]$ & $\mathrm{C}_{\mathrm{p}},{ }^{T} S^{o}, \Delta_{f}^{T} H^{o}, \Delta_{f}^{T} G^{o}$ & 298.15 to $1800 \mathrm{~K}$ & 20 \\
\hline $\mathrm{PuO}_{2}[\mathrm{cr}]$ & $\Delta_{f}^{T} H^{o}, \Delta_{f}^{T} G^{o}$ & 298.15 to $1500 \mathrm{~K}$ & 29 \\
\hline $\mathrm{SiO}_{2}$ [cr, quartz] & $\mathrm{C}_{\mathrm{p}},{ }^{T} S^{o}, \Delta_{f}^{T} H^{o}, \Delta_{f}^{T} G^{o}$ & 298.15 to $1800 \mathrm{~K}$ & 11 \\
\hline $\mathrm{ThO}_{2}[\mathrm{cr}]$ & $\mathrm{C}_{\mathrm{p}},{ }^{T} S^{o}, \Delta_{f}^{T} H^{o}, \Delta_{f}^{T} G^{o}$ & 298.15 to $1200 \mathrm{~K}$ & 11 \\
\hline $\mathrm{TiO}_{2}$ [cr, rutile] & $\mathrm{C}_{\mathrm{p}},{ }^{T} S^{o}, \Delta_{f}^{T} H^{o}, \Delta_{f}^{T} G^{o}$ & 298.15 to $1800 \mathrm{~K}$ & 11 \\
\hline $\mathrm{UO}_{2}[\mathrm{cr}]$ & $\mathrm{C}_{\mathrm{p},}{ }^{T} S^{o}, \Delta_{f}^{T} H^{o}, \Delta_{f}^{T} G^{o}$ & 298.15 to $1800 \mathrm{~K}$ & 11 \\
\hline $\mathrm{Yb}_{2} \mathrm{O}_{3}[\mathrm{cr}, \alpha]$ & $\mathrm{C}_{\mathrm{p}},{ }^{T} S^{o}, \Delta_{f}^{T} H^{o}, \Delta_{f}^{T} G^{o}$ & 298.15 to $1800 \mathrm{~K}$ & 20 \\
\hline $\mathrm{ZrO}_{2}[\mathrm{cr}]$ & $\mathrm{C}_{\mathrm{p}},{ }^{T} S^{o}, \Delta_{f}^{T} H^{o}, \Delta_{f}^{T} G^{o}$ & 298.15 to $1800 \mathrm{~K}$ & 11 \\
\hline $\mathrm{Ca}[\mathrm{cr}]$ & $\mathrm{C}_{\mathrm{p}},{ }^{T} S^{0}$ & 298.15 to $1800 \mathrm{~K}$ & 11 \\
\hline $\mathrm{Ce}$ [cr] & $\mathrm{C}_{\mathrm{p}},{ }^{T} S^{0}$ & 298.15 to $1800 \mathrm{~K}$ & 11 \\
\hline $\mathrm{Eu}[\mathrm{cr}]$ & $\mathrm{C}_{\mathrm{p}},{ }^{T} \mathrm{~S}^{O}$ & 298.15 to $1800 \mathrm{~K}$ & 20 \\
\hline $\mathrm{Gd}[\mathrm{cr}]$ & $\mathrm{C}_{\mathrm{p}},{ }^{T} \mathrm{~S}^{0}$ & 298.15 to $1800 \mathrm{~K}$ & 20 \\
\hline $\mathrm{Hf}[\mathrm{cr}]$ & $\mathrm{C}_{\mathrm{p}},{ }^{T} S^{0}$ & 0 to $6000 \mathrm{~K}$ & 2 \\
\hline $\mathrm{La}[\mathrm{cr}]$ & $\mathrm{C}_{\mathrm{p}},{ }^{T} S^{0}$ & 298.15 to $1800 \mathrm{~K}$ & 20 \\
\hline $\mathrm{Lu}[\mathrm{cr}]$ & $\mathrm{C}_{\mathrm{p}},{ }^{T} S^{o}$ & 298.15 to $1800 \mathrm{~K}$ & 20 \\
\hline $\mathrm{Nd}[\mathrm{cr}]$ & $\mathrm{C}_{\mathrm{p}},{ }^{T} S^{o}$ & 298.15 to $1800 \mathrm{~K}$ & 20 \\
\hline $\mathrm{O}_{2}[\mathrm{~g}]$ & $\mathrm{C}_{\mathrm{p}},{ }^{\mathrm{T}} S^{o}$ & 0 to $6000 \mathrm{~K}$ & 2 \\
\hline $\mathrm{P}[\mathrm{cr}]$, & $\mathrm{C}_{\mathrm{p}},{ }^{T} S^{O}$ & 0 to $6000 \mathrm{~K}$ & 2 \\
\hline $\mathrm{Pu}[\mathrm{cr}, \alpha]$ & $\mathrm{C}_{\mathrm{p}},{ }^{T} S^{O}$ & 260 to $873 \mathrm{~K}$ & 30 \\
\hline $\mathrm{Si}[\mathrm{cr}]$ & $\mathrm{C}_{\mathrm{p}},{ }^{T} S^{O}$ & 0 to $6000 \mathrm{~K}$ & 2 \\
\hline
\end{tabular}




\begin{tabular}{|l|l|l|l|}
\hline \multicolumn{1}{|c|}{ Compound } & \multicolumn{1}{|c|}{$\begin{array}{c}\text { Thermodynamic } \\
\text { Quantities Reported }\end{array}$} & $\begin{array}{c}\text { Valid Temperature } \\
\text { range. }\end{array}$ & \multicolumn{1}{|c|}{ Reference } \\
\hline $\mathrm{Th}[\mathrm{cr}]$ & $\mathrm{C}_{\mathrm{p}},{ }^{T} S^{\circ}$ & 298.15 to $1800 \mathrm{~K}$ & 11 \\
\hline $\mathrm{Ti}[\mathrm{cr}]$ & $\mathrm{C}_{\mathrm{p}},{ }^{T} S^{o}$ & 0 to $6000 \mathrm{~K}$ & 2 \\
\hline $\mathrm{U}[\mathrm{cr}]$ & $\mathrm{C}_{\mathrm{p}},{ }^{T} S^{o}$ & 298.15 to $1800 \mathrm{~K}$ & 11 \\
\hline $\mathrm{Yb}[\mathrm{cr}]$ & $\mathrm{C}_{\mathrm{p}},{ }^{T} S^{\circ}$ & 298.15 to $1400 \mathrm{~K}$ & 20 \\
\hline $\mathrm{Zr}[\mathrm{cr}]$ & $\mathrm{C}_{\mathrm{p}},{ }^{T} S^{\circ}$ & 0 to $6000 \mathrm{~K}$ & 2 \\
\hline
\end{tabular}

a. Data forthcoming from our laboratory. 
1 Record of Decision for the Surplus Plutonium Disposition. Final Environmental Impact Statement. January 4, 2000. US Department of Energy.

2 M. W. Chase Jr. NIST-JANAF Thermochemical Tables, Fourth Edition, J. Phys. Chem. Ref. Data, 1998, 9, pp. 1-1951.

3 N. E. Holden and R. L. Martin Pure Appl. Chem. 1983, 55, 1101.

4 CRC Handbook *****

5 R. L. Putnam Formation Energetics of Ceramic Waste Materials for the Disposal of Surplus Weapons Plutonium. Ph.D. Dissertation 1999 Princeton University.

6 R. L. Putnam, A. Navrotsky, B. F. Woodfield, J. Boerio-Goates, J. L. Shapiro J. chem. Thermodynamics 1999, 31, 229-243.

7 B. F. Woodfield, J. Boerio-Goates, J. L. Shapiro, R. L. Putnam, A. Navrotsky $J$. Chem. Thermodynamics 1999, 31, 245-253.

8 R. Stevens, B. K. Hom, J. Boerio-Goates, B. F. Woodfield, R. L. Putnam, A. Navrotsky J. Chem. Thermodynamics 2000, Submitted.

9 R. L. Putnam, J. Gutierriez, A. Navrotsky, R. Stevens, B. K. Hom, J. BoerioGoates, B. F. Woodfield J. Chem. Thermodynamics 2000, Submitted

10 Unpublished work. K. B. Helean, R. L. Putnam, A. Navrotsky Thermochemistry Facility, University of CA, Davis

11 R. A. Robie, B. S. Hemingway Thermodynamic Properties of Minerals and Related Substances at $298.15 \mathrm{~K}$ and 1 Bar (10^5 Pascals) Pressure and at Higher Temperatures. US Geological Survey Bulletin \#2131, 1995, United State Printing Office, Washington, D.C.

$12 \mathrm{H}$. Xu, Y. Wang J. Nucl. Mat. 1999, 275, 216-220.

13 Chemical Thermodynamics of Uranium H. Wanner and I. Forest eds. NorthHolland Press, New York. 1992.

14 R. D. Schuiling, L. Vergouwen, H. van der Rijst Am. Mineral.1976, 61, 166168.

15 L. A. Boatener and B. C. Sales in Radioactive Waste Forms for the Future W. Lutze and R. C. Ewing eds. North-Holland Press, New York 1988, pp. 495564.

16 Unpublished work, K. B. Helean, S. V. Ushakov, A. Navrotsky Thermochemistry Facility, University of CA, Davis

17 B. F. Woodfield, J. L. Shapiro, R. Stevens, R. L. Putnam, K.B. Helean, A. Navrotsky J. Chem. Thermodynamics 1999, 31, 1573-1583.

18 B. K. Hom, R. Stevens, B. F. Woodfield, J. Boerio-Goates, R. L. Putnam, K. B. Helean, A. Navrotsky $J$. Chem. Thermodynamics 2000, Accepted.

19 R. J. Silva, G. Bidoglio, M. H. Rand, P. B. Robouch, H. Wanner, I. Puigdomenech Chemical thermodynamics of americium Paris: OECD Nuclear Energy Agency, 1995, Elsevier, New York.

20 R. A. Robie, B. S. Hemingway, J. R. Fisher Thermodynamic Properties of Minerals and Related Substances at $298.15 \mathrm{~K}$ and $1 \mathrm{Bar}\left(10^{\wedge} 5\right.$ Pascals) Pressure and at Higher Temperatures. US Geological Survey Bulletin \#1452, 1979, United State Printing Office, Washington, D.C.

21 M.E. Huntelaar, A.S. Booij, E.H.P. Cordfunke, R.R van der Daan, A.C.G. van Genderen, J.C. van Miltenburg. J. Chem. Thermodynamics 2000, 32, 465-482.

22 A. N. Kornilov, I. M. Ushakova, W. S. Huber Jr., C. E. Holley Jr. J. Chem. Thermodynamics 1975, 7, 21-26. 
23 A. S. Coffinberry and F. H. Ellinger Proceedings of the International Conference on the Peaceful Uses of Atomic Energy, Geneva 1955, 9, 138-146. United Nations, New York

24 L. B. Pankratz Thermodynamic properties of elements and oxides 1982, US Bureau of Mines Bulletin, 672. US Government Printing Office.

25 L. R. Morss Thermodynamic Properties in The Chemistry of the actinide elements 2nd ed. J.J Katz, G. T. Seaborg, L. R. Morss eds Vol 2 London: Chapman and Hall, 1986, pp. $1278-1360$

26 J. D. Cox, D. D. Wagman, V. A. Medvedev CODATA Key Values for Thermodynamics 1984, Hemisphere Publishing Corp., New York.

27 H.R. Gardner, I. B. Mann "Mechanical Property and Formability Studies on Unalloyed Plutonium" in E. Grison, W.B.H. Lord, R.D. Fowler (eds) Plutonium 1960, 1961, Cleaver-Hume Press Ltd., London.

28 M. H. Rand Some key thermochemical data for plutonium compounds in: Thermo-dynamics 1965, Proc. Symp. Held 22-27 July 1965 in Vienna, Vienna: IAEA. Pp 603-611.

29 S. W. Rabideau J. Am. Chem. Soc. 1953, 75,798.

30 O. J. Wick (ed) Plutonium Handbook: A Guide to the Technology 1980, The American Nuclear Society, La Grange Park, IL. 